QUALITY

Volume 8, Nomor 2, 2020, 187-206

\title{
Implementasi Pendidikan Humanis Pada Pembelajaran Pendidikan Agama Islam di SMPN 1 Tulung
}

\author{
Salma Zhafiroh \\ IAIN Salatiga, Salatiga, Indonesia \\ salmazhafiroh123@gmail.com \\ Badrus Zaman \\ IAIN Salatiga, Salatiga, Indonesia \\ badruszaman@iainsalatiga.ac.id
}

\begin{abstract}
Abstrak
Tujuan yang hendak dicapai dalam penelitian ini adalah pertama, untuk mendeskripsikan implementasi pendidikan humanis pada pembelajaran Pendidikan Agama Islam di SMP N 1 Tulung, Klaten. Kedua, untuk mendiskripsikan faktor penghambat dan pendukung pendidikan humanis pada pembelajaran Pendidikan Agama Islam di SMP N 1 Tulung, Klaten. Jenispenelitian yang digunakan adalah penelitian deskriptif kualitatif. Teknik pengumpulan data dalam penelitian ini yaitu teknik observasi, wawancara dan dokumentasi. Selanjutnya data yang telah dikumpulkan dianlisis menggunakan metode triangulasi.Hasil penelitian menunjukkan bahwa implementasi pendidikan humanis pada pembelajaran pendidikan agama Islam berupa diskusi, pendampingan dan pembinaan. Sedangkan faktor pendukungnya adalah kreatifitas peserta didik dan kemajuan peserta didik untuk berfikirmengikuti perkembangan zaman, perhatian serta dukungan dari komite sekolah dan dalam setiap kelas jumlah peserta didiknya tidak banyak maka guru lebih mudah mengajar dan mempehatikan peserta didik. Adapun faktor penghambatnya yaitu kurangnya jumlah guru pendidikan agama Islam, kurangnya pemahaman mengenai pendidikan humanis dan kurangnya sarana prasarana penunjang pembelajaran.
\end{abstract}

Kata Kunci: Pendidikan Humanis, Pembelajaran PAI, Pendidikan Nilai 


\begin{abstract}
The objectives to be achieved in this study are first, describe the application of humanist education in the learning of Islamic Education in SMP N 1 Tulung, Klaten. Second, describe the inhibiting and supporting factors of humanist education in learning Islamic Education in SMP N 1 Tulung, Klaten. This type of research is a qualitative descriptive study. Data collection techniques in this study are observation, interview, and documentation techniques. Furthermore, the data collected was analyzed using the triangulation method. The results showed that the application of humanist education in Islamic religious education learning in the form of discussion, assistance, and coaching. While the supporting factors are student creativity and student progress to think in keeping with the times, the attention and support of the school committee, and in each class the number of students is not much, the teacher is easier to teach and notice students. The inhibiting factors are the lack of Islamic religious education teachers, lack of understanding of humanist education, and lack of learning support infrastructure.
\end{abstract}

Keyword: Humanist Education, PAI Learning, Value Education

\title{
A. Pendahuluan
}

Berbicara tentang pendidikan, pendidikan adalah sesuatu yang tidak ada habisnya, karena pada dasarnya pendidikan merupakan proses yang tidak pernah berakhir, ada juga ungkapan pendidikan seumur hidup (long life education). Dari ungkapan di atas terlihat bahwa betapa pentingnya pendidikan bagi seseorang, manusia dapat hidup layak di dunia ini karena memiliki pendidikan yang cukup baik dan orang akan menderita jika tingkat pendidikannya rendah. Pendidikan sebenarnya adalah sarana untuk membebaskan diri dari kebodohan, kemiskinan, penderitaan, penipuan dan penindasan. Bahkan banyak yang kini berubah menjadi wahana penggunaan kekerasan, terutama dalam kegiatan belajar mengajar (Rahman, 2013: 92).

Pendidikan sebagai kata benda berarti proses perubahan sikap dan perilaku seseorang dalam upaya mendewasakan manusia melalui upaya pengajaran dan pelatihan (Mahmud, 2011: 19). Dalam Undang-Undang Nomor 20 Tahun 2003, pendidikan merupakan upaya sadar dan terencana untuk menciptakan suasana 


\section{Salma Zhafiroh dan Badrus Zaman}

belajar dan proses pembelajaran agar peserta didik secara aktif mengembangkan potensi dirinya sehingga memiliki kekuatan spiritual keagamaan, kepribadian, pengendalian diri, kecerdasan, akhlak mulia. dan keterampilan yang dibutuhkan oleh diri sendiri, masyarakat, bangsa dan Berdasarkan hukum di atas, salah satu tujuan penyelenggaraan pendidikan adalah untuk mengembangkan potensi anak agar tercipta kekuatan pengendalian diri, kepribadian, kecerdasan, akhlak mulia dan sebagainya. di. Untuk mewujudkan hal tersebut, pemerintah harus mampu meningkatkan kualitas dan mutu pendidikan. Pemerintah tidak akan dapat merealisasikan tujuan tersebut jika dalam meningkatkan mutu pendidikan mengalami beberapa kendala, salah satunya adalah pembangunan yang kurang seimbang antara pendidikan umum dan pendidikan agama, karena pada dasarnya peningkatan mutu kedua pendidikan itu harus seimbang.

Pendidikan menggambarkan interaksi antara pendidik dan peserta didik dalam rangka mewujudkan visi pendidikan yang dilaksanakan di lembaga pendidikan formal dan nonformal. Pendidikan yang dilakukan pada dasarnya sama yaitu pembinaan diberikan agar peserta didik dapat hidup mandiri sehingga dapat melanjutkan dan memelihara tradisi dan nilai-nilai pembangunan sosial (Zaman, 2019: 130). Melalui pendidikan yang terencana, terkelola dengan baik dan intensif, maka titik pendidikan terbaik akan tercapai. Jika pendidikan dapat mengubah tingkah laku manusia ke arah yang positif, maka pendidikan itu dikatakan berhasil (Rochimah \& Zaman, 2018: 31).

Pendidikan yang terimplementasi konsep humanis yaitu suatu proses pembelajaran atau pendidikan yang menganut aliran humanisme, yang berarti suatu pendidikan yang mengedepankan manusia sebagai objek terpenting dalam sebuah pendidikan. Namun, objek di sini bukan sebagai penderita melainkan menempatkan sebagai subjek atau pelaku yang sebenarnya. Karena pendidikan humanis itu suatu pendidikan yang mengutamakan kepentingan manusia sebagai seorang yang merdeka dan mempunyai hak. Yang dimaksud hak disini yaitu manusia yang di 


\section{Salma Zhafiroh dan Badrus Zaman}

hargai orang lain dan manusia yang mempunyai potensi untuk berkarya, dan hak untuk diperlakukan sebagai manusia yang merdeka.

Ada dua hal yang perlu dikuasai setiap manusia yaitu pendidikan umum dan pendidikan agama agar masyarakat dapat menghadapi berbagai tantangan era globalisasi. Dengan memberikan pendidikan, mereka harus mampu melaksanakan proses pembelajaran yang akan menyadarkan peserta didik akan kebutuhan untuk belajar. Bahan ajar setidaknya dapat memberikan alternatif pembelajaran bagi peserta didik dan dapat memberikan motivasi untuk hidup di zaman sekarang. Belajar tidak akan cukup jika ditularkan hanya dalam bentuk keterampilan bagi diri sendiri, tetapi juga untuk hidup bertetangga dalam masyarakat, dan tidak ada perbedaan diantara keduanya.

Menurut Zakiah Daradjat (2015: 3) PAI merupakan usaha yang dilakukan untuk membina dan membimbing peserta didik agar mampu menjalankan ajaran Islam secara komprehensif kemudian Islam dijadikan sebagai way of life. Badrus Zaman (2020: 120) mendefinisikan PAI ialah upaya sadar berupa bimbingan dan pengajaran terhadap peserta didik, guna mengembangkan potensi jasmani maupun rohani berdasarkan nilai-nilai spiritual dan kemanusiaan agar setelah memperoleh pembelajaran setiap peserta didik mampu mengamalkan ajaran agama Islam, serta terbentuk kepribadian muslim yang memiliki sifat dan amal perbuatan berdasarkan ajaran agama Islam. Sedangkan Zuhairini (2004: 11) mendefinisikan PAI adalah upaya sadar guna membina ke arah pembangunan karakter peserta didik secara terpadu dan realistis,agar hidup sesuai dengan ajaran agama Islam, sehingga tercapaikeselamatan hidup dunia dan akhirat.Tayar Yusuf mengartikan PAI sebagai upaya sadar generasi lama untuk mentransformasikan pengalaman, wawasan, keahlian, dan kompetensi kepada generasi baru supaya menjadi manusia bertakwa kepada Allah (Majid \& Andayani, 2004: 130).

Dalam pelaksanaan pendidikan agama Islam sering mendapatkan kritik dan selalu diragukan dalam pembelajarannya oleh berbagai pihak, antara lain yaitu orang tua, sekolah maupun masyarakat pada umumnya. Padahal pendidikan agama 


\section{Salma Zhafiroh dan Badrus Zaman}

Islam adalah suatu mata pelajaran yang di yakini semua pihak sebagai salah satu mata pelajaran yang berfungsi untuk memperbaiki kondisi moral generasi masa depan.

Kegiatan pembelajaran di sekolah memiliki berbagai macam cara yang digunakan, cara tersebut yaitu disesuaikan dengan mata pelajaran dan peserta didik yang diberi pelajaran. Pembelajaran pendidikan agama Islam di sekolah pada umumnya masih dalam tataran materi agama Islam saja, dapat dilihat dari metode yang digunakan oleh guru yang berupa ceramah, dimana metode ini masih mendominasi atau paling banyak digunakan guru dalam dunia pendidikan, karena pada umumnya guru sudah terbiasa, belum merasa puas dan mengajar apabila belum banyak berceramah. Fatmawati, Setyowati, \& Utomo (2017: 89) berpendapat bahwa pembelajaran yang berpusat pada guru harus diubah dengan berpusat pada peserta didik.

Maka dari itu saatnya kita mengubah model pendidikan agama Islam yang masih mengikuti gaya lama dan yang hanya menuntut peserta didik untuk selalu patuh dan tidak memberikan kebebasan untuk berfikir kritis dan rasional untuk menuju pendidikan agama Islam yang mencerdaskan, memerdekakan dan memanusiakan sehingga pendidikan agama Islam yang humanis akan terwujud. Kita sebagai guru harus menciptakan suasana agar pembelajaran di sekolah berlangsung secara efektif, inovatif, kreatif dan menyenangkan serta tidak membuat anak terbebani (Suyono \& Haryanto, 2011: 11).

Sebenarnya tujuan akhir dari pendidikan agama Islam adalah untuk mengembangkan potensi anak didik secara optimal, sehingga dalam hal pendidikan mampu berperan sebagai proses memanusiakan manusia. Untuk mencapai tujuan itu, diperlukan upaya agar peserta didik menjadi manusia yang bertanggung jawab terhadap tuhannya, dirinya, keluarganya, bangsa serta negaranya. Dalam dunia pendidikan terutama peserta didik untuk mengembangkan diri dan potensi yang dimilikinya secara maksimal, dengan harapan bahwa pendidikan agama Islam mampu menjalankan fungsinya sebagai saran pemberdayaan dan humanisasi. 


\section{Salma Zhafiroh dan Badrus Zaman}

Dalam pendidikan yang humanis, peserta didik dipandang sebagai makhluk unik yang memiliki berbagai potensi dan kecerdasan yang berbeda-beda. Dengan demikian, guru harus menciptakan pembelajaran yang demokratis, mengakui hak anak untuk melakukan tindakan belajar sesuai karakteristiknya.

Setiap anak mempunyai kelemahan disamping kekuatan yang dimilikinya, keberanian di samping rasa takutnya, bisa marah, kecewa dan gembira. Hal tersebut yang membuat karakteristik setiap anak berbeda, jadi wajar jika ada anak pintar dan kurang pintar, berbakat dan tidak berbakat. Keragaman inilah yang membuat munculnya berbagai macam kecerdasan pada anak yang dapat mempengaruhi cara pembelajaran yang digunakan seorang guru. Tidak semua anak dapat memahami pelajaran yang disampaikan guru, ketika ulangan wajar jika ada murid yang mendapat nilai bagus, cukup bagus atau mendapat nilai jelek. Walau dipaksa atau diancam, jika murid tersebut belum paham maka tentu tidak bisa mengerjakan soal.

Sifat dan karakter anak yang berbeda-beda juga akan menghasilkan tindakan yang berbeda entah itu tingkah laku pribadi maupun sosial. Tingkah laku sosial anak berasal dari lingkungan yang kurang baik, tetapi akan berbeda dengan tingkah laku anak berasal dari lingkungan yang baik. Tingkah laku sosial anak seperti halnya tolong menolong kepada sesama atau yang lebih tua, saling menghormati, menjujung tinggi hak dan kewajiban seseorang dan lainnya yang harus dikembangkan. Maka pendidikan yang diberikan kepada peserta didik di sekolahan tidak hanya pendidikan umum saja, tetapi juga diberikan pendidikan agama dan pendidikan humanis.

Perubahan perilaku peserta didik merupakan suatu keniscayaan yang tidak bisa dipungkiri, karena hal tersebut merupakan hakikat dan sangatlah manusiawi. Dalam kondisi tersebut perubahan dapat membawa dampak yang baik maupun buruk tergantung bagaimana kita memposisikan diri kita. Berbicara tentang perubahan tidak bisa lepas dari manusia sebagai subjek perubahan itu sendiri. 


\section{Salma Zhafiroh dan Badrus Zaman}

Pada dasarnya guru sudah berusaha untuk menanamkan pendidikan humanis dalam pendidikan agama Islam pada diri peserta didik. Tetapi karena perbedaan latar belakang setiap anak mungkin guru dituntut agar mengembangkan cara atau metode supaya pendidikan humanis bisa diterapkan oleh setiap anak tanpa melihat darimana dia berasal. Dengan adanya implementasi pendidikan humanis ini guru berharap peserta peserta didik bisa menerapkannya dalam kehidupan seharihari seperti, menunjukkan rasa tanggung jawab terhadap sesama, saling menghormati dan menjunjung tinggi nilai-nilai pluralisme (Zafi, 2020: 67).

SMP N 1 Tulung ini adalah suatu lembaga pendidikan yang sebagian besar muridnya adalah anak-anak yang ditinggal orang tuanya berpisah (broken home), yatim piatu dan lainnya. Anak-anak seperti inilah yang harus mendapatkan perlakuan khusus dari pendidik atau guru di suatu lembaga pendidikan (dalam hal ini SMP N 1 Tulung) notabennya anak seperti cenderung melawan, susah diatur, dan mendapat bullying dari teman-temannya. Dikarenakan sebelum mengenal suatu lembaga pendidikan, anak melihat kejadian-kejadian yang seharusnya mereka belum patut untuk mengetahuinya misalnya, anak dari keluarga yang tidak harmonis setiap hari anak selalu di hadapkan pada suatu pertengkaran kedua orang tuanya, terkadang juga melakukan adegan fisik, dan dibullying teman-temannya. Berawal dari itulah pola pikir anak tersimpan memori yang berupa kekerasan yang terjadi dikeluarga dan lingkungan sekolah adalah suatu hal yang selalu diingat dalam benak pikirannya, bukan kasih sayang (Observasi 2020).

Berasal dari permasalahan itu maka penulis berkeinginan untuk mengamati tentang bagaimana Implementasi Pendidikan Humanis pada Pembelajaran Pendidikan Agama Islam di SMP N 1 Tulung?, apa saja faktor pendukung dan penghambat implementasi pendidikan humanis pada pembelajaran Pendidikan Agama Islamdi SMP N 1 Tulung? Dalam penelitian ini, penulis bertujuan untuk mendiskripsikan implementasi pendidikan humanis dan untuk mendiskripsikan faktor pendukung dan penghambat implementasi pendidikan humanis pada pembelajaran Pendidikan Agama Islamdi SMP N 1 Tulung Tahun 2020. 


\section{Salma Zhafiroh dan Badrus Zaman}

Metode penelitian yang digunakan oleh penulis dalam penelitian ini adalah metode riset lapangan (field reseach), yaitu penelitian secara langsung terhadap obyek yang akan diteliti (Arikunto, 1998: 100). Jenis penelitian ini merupakan jenis penelitian kualitatif. Penelitian kualitatif ini merupakan prosedur penelitian yang menghasilkan data deskriptif berupa kata-kata tertulis atau lisan dari orang-orang dan perilaku yang dapat diamati (Moeleng, 2009: 4). Penelitian ini digunakan untuk mendeskripsikan tentang segala sesuatu yang berkaitan dengan implementasi pendidikan humanis pada pembelajaran pendidikan agama Islam di SMP N 1 Tulung.

Untuk mendapatkan data yang benar-benar valid dalam penelitan, perlu ditentukan teknik-teknik pengumpulan data yang sesuai, maka peneliti menggunakan teknik triangulasi. Triangulasi diartikan sebagai teknik pengumpulan data dan sumber data yang telah ada. Dengan triangulasi berarti peneliti menggunakan teknik pengumpulan data yang berbeda-beda untuk mendapatkan dari sumber yang sama. Maka peneliti menggunakan observasi, wawancara dan dokumentasi untuk sumber data yang sama (Sugiyono, 2016: 33).

\section{B. Pembahasan}

Paham humanis seharusnya berpandangan bahwa ilmu pengetahuan digali dan dikembangkan agar manusia dimanusiakan dan memanfaatkan ilmu pengetahuan sepenuhnya untuk kehidupan manusia. Selain itu dalam paradigma humanis, manusia dipandang sebagai makhluk Allah yang memiliki fitrah-fitrah tertentu dan harus dikembangkan secara optimal, fitrah manusia harus bisa dikembangkan melalui pendidikan yang benar-benar memanusiakan manusia (Solichin, 2018: 14).

Konsep pendidikan humanis adalah suatu konsep yang membahas mengenai manusia, yang meliputi tujuan hidup manusia, hak dan kewajiban manusia, serta potensi-potensi yang dimiliki oleh manusia. Dalam tataran pendidikan agama Islam konsep pendidikan humanis sangat dijunjung tinggi, karna sangat berkaitan erat 


\section{Salma Zhafiroh dan Badrus Zaman}

dengan pendidikan agama Islam yang menganggap manusia adalah makhluk yang paling sempurna di muka bumi ini dibandingkan ciptaan Allah yang lainnya (Safitri \& Zafi, 2020: 83). Dengan adanya konsep pendidikan humanis hak dan kewajiban manusia bisa lebih di perhatikan oleh manusia yang lainnya. Sama halnya dengan potensi manusia jika konsep tersebut tidak diterapkan dalam pembelajaran maupun pendidikan maka manusia tidak akan bisa mengembangkan potensi yang dimilikinya.

Dalam implementasi konsep pendidikan humanis juga harus memperhatikan acuan yang digunakan yaitu indikator konsep pendidikan humanis. Indikator tersebut berguna untuk menjadikan dasar seorang guru dalam menerapkan konsep pendidikan humanis dalam pembelajaran, khususnya pembelajaran pendidikan agama Islam, indikator tersebut meliputi: akal sehat, mementingkan fungsi dari pada simbol, kemandirian, pengetahuan yang tinggi, dan keseimbangan antara reward dan punishmen.

Akal sehat yaitu suatu alat rohaniah yang bisa untuk berfikir, menganalisis dan menyimpulkan suatu hal dalam kategori baik ataupun buruk. Manusia dibedakan dengan makhluk lain dari ciptaan Allah juga dari akal, hawa nafsu dan perasaan. Dengan akal juga manusia di angkat derajatnya oleh Allah, karena akal yang di manfaatkan dengan sebaik-baiknya dan sesuai dengan ajaran Allah maka akan menghasilkan ilmu yang bermanfaat .

Kaitannya dengan pendidikan agama Islam, ada pembelajaran dalam pendidikan agama Islam yang bisa difikirkan dengan akal dan ada juga yang tidak. Contohnya seperti wujud Allah, wujud pahala dan seterusnya, itu semua adalah hal yang abstrak yang tidak bisa mengetahui wujud nyatanya. Namun hal yang tidak bisa kita cerna dengan akal tersebut dapat kita qiyaskan dengan hasilnya, suatu hasil tidak akan ada jika tidak ada usaha. Contohnya, kita bersedekah kepada pengemis, sesuai janji Allah akan diganti menjadi 700 kali lipat, tanpa kita sangka, kita mendapatkan rejeki di kemudian hari lebih banyak dari itu bahkan beribu-ribu kali lipat. Jadi dapat kita simpulkan bahwa sesuatu hal yang tadinya tidak bisa kita 


\section{Salma Zhafiroh dan Badrus Zaman}

ketahui wujudnya, pada saatnya nanti kita akan mengetahui wujudnya dalam bentuk yang berbeda-beda.

Yang kedua yaitu kemandirian, kemandirian adalah bekal yang harus ditanamkan pada diri seorang peserta didik. Dengan tersebut peserta didik tidak akan mudah tergantung pada orang lain, tidak mudah putus asa dan berusaha dengan kemampuannya terlebih dahulu. Kemandirian akan berjalan secara seimbang dengan pengetahuan tinggi yang dimilikinya oleh peserta didik. Pengetahuan yang tinggi tersebut akan didapat peserta didik, jika peserta didik bisa memahami fungsi daripada simbol maksutnya adalah belajar tidak harus dibangku sekolah atau di dalam kelas, belajar itu bisa dilakukan dimana saja.

Jika memang pembelajaran dilakukan di dalam kelas, maka pembelajaran tersebut harus di sangkut pautkan dengan kejadian sehari-hari yang di alami oleh peserta didik. Dengan guru menyangkut pautkan pembelajaran dengan kejadian sehari-hari yang di alami oleh peserta didik, maka materi yang disampaikan itu akan mudah di cerna dan di implementasikan oleh peserta didik dalam kehidupannya. Di SMP N 1 Tulung ini kemandirian peserta didik bisa tercermin dari tingkah laku peserta didik diantaranya, mengerjakan ulangan dengan baik, merapikan tempat duduk, berusaha mencoba menyelesaikan masalahnya sendiri. Oleh karena itu, sebagai guru selain memahami akan ilmu pedagogik, juga harus tahu bagaimana cara menata peserta didik agar siap menghadapi masa depannya. Kemandirian dan pengetahuan yang tinggi akan berjalan beriringan karena dengan pengetahuan yang tinggi sifat kemandirian dalam diri peserta didik akan muncul dengan sendirinya.

Setelah kemandirian muncul dari dalam diri peserta didik karena mendapatkan pengetahuan yang baru, sebagai guru kita harus menerapkan sikap pluralisme atau saling menghormati, saling memahami antar perbedaan. Apalagi di SMP N 1 Tulung ini banyak sekali perbedaan, dari perbedaan latar belakang, strata sosial, keturunan maupun yang lainnya. Sudah sewajarnya kita harus menghormati dan menghargai perbedaan peserta didik-siswi di SMP N 1 Tulung, pluralisme 


\section{Salma Zhafiroh dan Badrus Zaman}

sangat terjalin dan terimplementasikan dengan baik, tanpa melihat latar belakang keluarga, ras, dan suku peserta didik-siswi disini berteman dengan baik tanpa ada diskriminasi. Sama halnya dengan guru-guru disini dalam memberikan pengajaran guru tidak pernah membeda-bedakan antara peserta didik satu dengan peserta didik lainnya.

Setelah pluralisme atau sikap saling menghargai tersebut sudah diimplementasikan oleh peserta didik-siswi SMP N 1 Tulung ini, guru disini akan memberikan hadiah atau reward serta punishmen bagi peserta didik-siswi yang tidak taat akan aturan dan bagi peserta didik yang melanggar. Dalam lingkungan SMP N 1 Tulung ini reward dan punishmen sudah terimplementasikan secara seimbang misalnya, untuk anak yang mendapat nilai bagus dan taat akan segala peraturan yang ada atau yang telah mengharumkan almamater sekolah tersebut, maka akan mendapatkan hadiah, berupa alat tulis, peralatan sekolah atau uang. Namun bagi yang melanggar juga mendapatkan hukuman, hukuman yang diberikan kepada peserta didik adalah hukuman yang mendidik, mengikuti kebijakan dari bapak atau ibu guru yang bersangkutan seperti menghafalkan surat-surat pendek Al-Qur'an. Jika anak tersebut berusaha memperbaiki kesalahannya dan menyesal serta berjanji tidak akan mengulanginya lagi, anak tersebut juga akan mendapat hadiah atas usahanya.

Disinilah keseimbangan antara reward dan punishmen mulai nampak. Ada perhatian khusus bagi setiap anak, baik yang berperilaku baik, buruk atau yang berusaha memperbaiki kesalahannya.

\section{Implementasi Pendidikan Humanis pada Pembelajaran Pendidikan Agama Islam di SMP N 1 Tulung Klaten}

SMP Negeri 1 Tulung adalah sekolah menengah pertama yang dibawah naungan pemerintah daerah. Walaupun di bawah naungan pemerintah daerah pendidikan agama Islamnya juga tidak jauh berbeda dengan sekolah lain yang berbasis agama Islam. Yang membuat sekolah ini sedikit istimewa karena peserta 


\section{Salma Zhafiroh dan Badrus Zaman}

didik yang bersekolah di SMP Negeri 1 Tulung berasal dari keluarga broken home, yatim piatu dan yang lainnya. Dalam tatanan pendidikan tidak boleh membedabedakan antara peserta didik satu dengan peserta didik yang lainnya dari segi apapun. Peserta didik harus memperoleh haknya sebagai peserta didik dan diperlakukan sebagai manusia seutuhnya, serta terpenuhi akan hak dan kewajibannya (Observasi, 2020).

Dalam memenuhi hak dan kewajiban peserta didik, maka SMP N 1 Tulung ini menerapkan pendidikan humanis pada pembelajaran pendidikan agama Islam. Pendidikan humanis yang diterapkan di sekolah ini yaitu memilih enam indikator sebagai tujuan agar implementasi pendidikan humanis ini terlaksanakan dengan benar. Keenam indikator tersebut adalah, akal sehat, tanggung jawab, pluralisme (saling menghargai dan menghormati), pengetahuan yang tinggi, menuju kemandirian, mementingkan fungsi daripada simbol dan keseimbangan antara reward dan punishment.

Tidak jauh berbeda dengan pendidikan humanis, pendidikan agama Islam pun juga mempunyai indikator sebagai tujuan pembelajaran. Indikator pendidikan agama Islam yaitu, Iman (Aqidah),Islam (Syariah), Ihsan (Akhlak). Berdasarkan data yang peneliti dapatkan kemudian disimpulkan, bahwasanya di dalam implementasi pendidikan humanis pada pembelajaran pendidikan agama Islam dapat di terapkanmelalui beberapa kegiatan.

Dari hasil wawancara implementasi pendidikan humanis pada pembelajaran pendidikan agama Islam di SMP N 1 Tulung Kabupaten Klaten guru PAI menerapkan melalui beberapa kegiatan yaitu sebagai berikut: Pertama, diskusi. Diskusi yaitu suatu metode yang biasa digunakan oleh sebagian besar guru untuk meningkatkan keberanian dan keaktifan serta kepercayaan diri peserta didik. Dengan melalui diskusi tersebut peserta didik dituntut untuk berani mengeluarkan pendapatnya dan bertanggung jawab atas pendapat yang sudah dikeluarkan. Disini guru hanya sebagai fasilitator, yang apabila menemukan kendala atau kesulitan dalam menentukan pilihan guru memberikan acuan untuk di sepakati bersama. 


\section{Salma Zhafiroh dan Badrus Zaman}

Sesuai dengan indikator pendidikan humanis yaitu diskusi yang dilakukan seorang peserta didik di setiap kesempatan yang ada dan pada waktu pembelajaran pendidikan agama Islam serta melatih anak untuk berfikir dan menyampaikan ide atau gagasan mereka kepada orang lain. Dalam arena diskusi tidak hanya terdiri dari pelajar saja, akan tetapi para pendamping atau guru juga ikut didalamnya. Prinsipnya dalam metode diskusi ini peserta didik saling menghormati dan menghargai pendapat peserta didik lain yang berbeda dengannya.

Mereka akan bisa bertukar pendapat antara satu dengan yang lainnya, dengan materi keagamaan yang disajikan sebagai pokok pembahasan diskusi juga bervariasi atau berbeda-beda, mulai dari materi mengenai ibadah yang meliputi sholat, puasa, zakat dan tanda-tanda hari kiamat, serta materi yang meliputi pendidikan Islam seperti keimanan dan aturan yang harus dikerjakan serta ditinggalkan atau hukum yang ada dalam agama Islam (Wawancara 2020).

Kedua, pendampingan peserta didik. Pendampingan terhadap peserta didik diterapkan di sekolah ini, tujuannya untuk membantu peserta didik memecahkan masalah yang dihadapi. Dengan adanya pendampingan terahadap peserta didik ini juga tidak lepas dari tujuan humanis yaitu memanusiakan manusia. Dengan memberikan pendampingan kepada peserta didik dalam memecahkan masalah maka peserta didik akan merasa diperhatikan oleh guru. Dengan adanya keberadaan pendamping yang bertujuan sebagai fasilitator, maka keputusan diserahkan kepada para peserta didik akan tetapi jika terjadi kendala maka pendamping akan memberikan sedikit jawaban sebagai rangsangan atau stimulan untuk mempertajam analisa peserta didik dalam memecahkan masalah.

Pendampingan disini antara lain bertujuan untuk membantu peserta didik memecahkan masalah yang sedang di hadapinya, juga bermaksud untuk mendampingi peserta didik agar lebih giat dan semangat dalam belajar. Karena semangat dari dalam diri anak itu sendiri dalam belajar itulah yang nantinya peserta didik mulai berfikir posesif, kreatif dan berfikir mengikuti perkebangan zaman. Adanya pendampingan peserta didik juga untuk membuktikan bahwa seluruh 


\section{Salma Zhafiroh dan Badrus Zaman}

peserta didik SMP N 1 Tulung ini diperhatikan oleh guru baik dalam perbuatan maupun saat dalam pembelajaran. Dengan cara seperti ini peserta didik akan lebih bersemangat dalam belajar dan mencari ilmu (Wawancara 2020).

Ketiga, pembinaan (konseling). Melalui pembinaan ini guru dapat mengetahui secara detail dan mendalam pada persoalan maupun kesulitan yang di hadapi oleh peserta didik. Pemahaman tentang persoalan yang dihadapi oleh peserta didik akan mempermudah pendamping untuk memberikan arahan atau masukan untuk menentukan langkah-langkah terkait dengan pemecahan masalah yang di hadapinya. Pembinaan yang dilaksanakan di SMP N 1 Tulung ini di rasa sangat perlu dilakukan. Karena anak-anak berasal dari latar belakang yang berbeda-beda dan karakter anak yang berbeda-beda juga. Untuk memudahkan guru dalam mengatur peserta didik-peserta didiknya dan memperbaiki karakter peserta didik maka pembinaan ini dirasa perlu dilakukan oleh pihak sekolah.

Dalam melaksanakan pembinaan guru tidak langsung memanggil peserta didik, tidak seperti momok terdahulu bahwa setiap di adakan pembinaan pasti peserta didik akan melakukan pelanggaran. Sekarang tidak seperti itu, tetapi sekarang yang dinamakan pembinaan adalah usaha dalam mengenal peserta didik lebih dalam dengan tujuan merubah pribadi peserta didik dan menumbuhkan karakter peserta didik serta untuk menggali potensi-potensi peserta didik yang bisa dikembangkan. Dalam pembinaan ini guru juga sering memberikan motivasimotivasi kepada peserta didik agar peserta didik rajin bersekolah, rajin belajar, rajin beribadah dan menyemangati untuk keberlangsungan hidup peserta didik agar tidak mudah putus asa (Wawancara 2010).

\section{Faktor Pendukung dan Penghambat Implementasi Pendidikan Humanis pada Pembelajaran Pendidikan Agama Islam di SMP N 1 Tulung Klaten}

Implementasi pendidikan humanis dalam pembelajaran pendidikan agama Islam di SMP N 1 Tulung sangat baik, dengan adanya pendidikan humanis dalam pembelajaran pendidikan agama Islam peserta didik dapat memaksimalkan potensi 


\section{Salma Zhafiroh dan Badrus Zaman}

yang mereka miliki. Sesuai dengan pengertian humanis yang disampaikan oleh guru agama bahwa humanis adalah suatu konsep yang membahas mengenai potensi manusia, yang dimana potensi tersebut di kembangkan melalui beberapa programprogram pembelajaran. Di sekolah ini implementasi pendidikan humanis bisa dikatakan berjalan dengan lancar, sebab ada faktor pendukung yang mengiringi kesuksesan implementasi pendidikan humanis di sekolah ini. Walaupun pada awalnya pendidikan humanis ini terlalu sedikit sulit diterapkan di sekolahan ini, namun selang beberapa waktu bisa di rasakan keberhasilan dalam implementasi pendidikan humanis tersebut.

Faktor yang mendukung implementasi pendidikan humanis diantaranya yaitu adanya kemauan dari peserta didik untuk berfikir modern atau berfikir secara maju. Berfikir secara maju adalah berfikir mengikuti perkembangan zaman yang selalu berubah-ubah. Berubah-ubahnya zaman tersebut disebabkan karena dampak globalisasi dan modernisasi yang tidak kenal batas. Pada zaman modern ini jika peserta didik tidak bisa mengikuti perkembangan zaman yang semakin maju dan canggih ini, mereka akan tertinggal jauh dengan peradabannya.

Selain itu faktor pendorong yang diterapkan dalam pendidikan humanis di SMP N 1 Tulung adalah adanya dukungan dari komite sekolah. Dengan adanya perhatian dari komite sekolah menjadi nilai tambah tersendiri bagi para pihak sekolah karena selain diperhatikan berarti komite juga menginginkan SMP N 1 Tulung ini menjadi sekolah yang sama dengan sekolah yang lainnya khususnya di daerah Klaten.

Faktor pendukung implementasi pendidikan humanis pada pembelajaran pendidikan agama Islam ini tidak akan terealisasi mendukung implementasi pendidikan humanis jika tidak di pahami benar-benar, maka dari itu SMP N 1 Tulung mulai berbenah agar implementasi pendidikan humanis ini terimplementasikan dengan baik. Jumlah peserta didik dalam setiap kelas yang tidak cukup banyak sehingga memudahkan guru untuk mengajar dan memperhatikan peserta didik. Dan ketika dalam proses belajar mengajar peserta 


\section{Salma Zhafiroh dan Badrus Zaman}

didik juga lebih mudah untuk menangkap materi yang sudah diajarkan oleh gurunya.

Dalam implementasi pendidikan humanis di SMP N 1 Tulung, selain ditemukan faktor pendukung juga ditemukan faktor penghambatnya dalam implementasi pendidikan humanis pada pembelajaran pendidikan agama Islam. Menurut kepala sekolah ini, faktor penghambatnya dalam implementasi pendidikan humanis muncul dari beberapa faktor, di antaranya muncul dari faktor internal dan faktor eksternal. Faktor penghambat yang muncul dari faktor internal yaitu kurangnya guru pendidikan agama yang ada di SMP N 1 Tulung.

Jadi guru agama Islam menjadi elemen yang sangat penting dalam implementasi pendidikan humanis khususnya di dalam pembelajaran pendidikan agama Islam, dan akan lebih maksimalnya lagi jika guru yang mengampu pelajaran tersebut harus konsen terhadap satu lembaga pendidikan saja. Jadi karena guru menjadi elemen terpenting dalam implementasi pendidikan humanis pada pembelajaran pendidikan agama Islam maka guru harus penuh mengajar di satu lembaga pendidikan saja.

Selain kurangnya jumlah guru yang ada di SMP N 1 Tulung faktor penghambat yang lainnya yaitu kurangnya pemahaman guru mengenai pendidikan humanis. Sebenarnya guru sudah memahami pendidikan humanis, namun pemahaman guru terhadap pendidikan humanis hanya sebatas mengerti saja, belum memahami sampai akar-akarnya. Padahal disini guru sebagai pentransfer pengetahuan atau ilmu mengenai pendidikan humanis, namun guru belum paham secara keseluruhan mengenai pendidikan humanis.

Faktor penghambat selanjutnya yaitu, mengenai sarana dan prasarana, sarana dan prasarana adalah suatu hal yang sangat mendukung dalam penyampaian pembelajaran. Namun sesuai keadaan yang peneliti lihat pada sarana dan prasarana di SMP N 1 Tulung masih sangatlah kurang. Belum bisa dikatakan membantu dalam terselenggaranya implementasi pendidikan humanis, sebab mengapa ? 


\section{Salma Zhafiroh dan Badrus Zaman}

Karena kurangnya perawatan, di perbaiki dan dirawat mungkin sarana dan prasarananya akan menjadi berfungsi kembali dan mendukung implementasi pendidikan humanis dalam pembelajaran pendidikan agama Islam.

Jadi dapat di simpulkan bahwa faktor pendukung pendidikan humanis dalam pembelajaran pendidikan agama Islam di SMP N 1 Tulung meliputi, adanya perhatian dan dukungan dari komite sekolah dan adanya kemauan peserta didik untuk berfikir maju mengikuti perkembangan zaman serta dengan adanya jumlah yang tidak cukup banyak sehingga memudahkan guru untuk mengajar dan memperhatikan peserta didik.

Sedangkan faktor penghambat implementasi pendidikan humanis adalah kurangnya jumlah guru agama Islam yang ada di SMP N 1 Tulung, kurangnya pemahaman mengenai pendidikan humanis dan kurangnya sarana dan prasarana yang menunjang keberhasilan dan kenyamanan dalam proses pembelajaran.

Agar dapat berjalan dengan baik implementasi pendidikan humanis dalam pembelajaran pendidikan agama Islam di SMP N 1 Tulung yaitu sekolah mengadakan workshop dan pelatihan tentang penerapan pendidikan humanis di sekolah serta menambah guru PAI agar dapat secara intens menangani peserta didik yang mengalami permasalahan dalam pembelajaran dan permasalahan baik di lingkungan keluarga, masyarakat, dan sekolah.

\section{Simpulan}

Implementasi pendidikan humanis pada pembelajaran pendidikan agama Islam di SMP N 1 Tulung Kabupaten Klatenguru PAI menerapkan melalui beberapa kegiatanya itu sebagai berikut: Pertama, diskusi: diskusi yaitu suatu metode yang biasa digunakan oleh sebagian besar guru untuk meningkatkan keberanian dan keaktifan serta kepercayaan diri peserta didik. Dengan melalui diskusi tersebut peserta didik dituntut untuk berani mengeluarkan pendapatnya dan bertanggung jawab atas pendapat yang sudah dikeluarkan. Disini guru hanya sebagai fasilitator, yang apabila menemukan kendala atau kesulitan dalam 


\section{Salma Zhafiroh dan Badrus Zaman}

menentukan pilihan guru memberikan acuan untuk disepakati bersama. Prinsipnya dalam metode diskusi ini peserta didik saling menghormati dan menghargai pendapat peserta didik lain yang berbeda dengannya. Kedua, pendampingan peserta didik: pendampingan terhadap peserta didik diterapkan di sekolah ini, tujuannya untuk membantu peserta didik memecahkan masalah yang dihadapi. Dengan adanya pendampingan terahadap peserta didik ini juga tidak lepas dari tujuan humanis yaitu memanusiakan manusia. Dengan memberikan pendampingan kepada peserta didik dalam memecahkan masalah maka peserta didik akan merasa diperhatikan oleh guru. Pendampingan disini antara lain bertujuan untuk membantu peserta didik memecahkan masalah yang sedang di hadapinya, juga bermaksud untuk mendampingi peserta didik agar lebih giat dan semangat dalam belajar. Karena semangat dari dalam diri anak itu sendiri dalam belajar itulah yang nantinya peserta didik mulai berfikir posesif, kreatif dan berfikir mengikuti perkebangan zaman. Adanya pendampingan peserta didik juga untuk membuktikan bahwa seluruh peserta didik SMP N 1 Tulung ini diperhatikan oleh guru baik dalam perbuatan maupun saat dalam pembelajaran. Dengan cara seperti ini peserta didik akan lebih bersemangat dalam belajar dan mencari ilmu. Ketiga, pembinaan (konseling): melalui pembinaan ini, para guru dapat mengetahui secara detail dan mendalam pada persoalan maupun kesulitan yang di hadapi oleh peserta didik. Pemahaman tentang persoalan yang di hadapi oleh peserta didik akan mempermudah pendamping untuk memberikan arahan atau masukan untuk menentukan langkah-langkah terkait dengan pemecahan masalah yang di hadapinya. Pembinaan yang dilaksanakan di SMP N 1 Tulung ini di rasa sangat perlu dilakukan. Karena anak-anak berasal dari latar belakang dan karakteranak yang berbeda-beda. Untuk memudahkan guru dalam memperbaiki karakter peserta didik maka pembinaan ini dirasa perlu dilakukan oleh pihak sekolah.

Faktor pendukung implementasi pendidikan humanis dalam pembelajaran pendidikan agama Islam di SMP N 1 Tulung meliputi, adanya perhatian dan dukungan dari komite sekolah dan adanya kemauan peserta didik untuk berfikir 
maju mengikuti perkembangan zaman serta dengan adanya jumlah yang tidak cukup banyak sehingga memudahkan guru untuk mengajar dan memperhatikan peserta didik. Sedangkan faktor penghambat implementasi pendidikan humanis adalah kurangnya jumlah guru agama Islam yang ada di SMP N 1 Tulung, kurangnya pemahaman mengenai pendidikan humanis dan kurangnya sarana dan prasarana yang menunjang keberhasilan dan kenyamanan dalam proses pembelajaran.

Agar dapat berjalan dengan baik implementasi pendidikan humanis dalam pembelajaran pendidikan agama Islam di SMP N 1 Tulung adalah sekolah mengadakan workshop dan pelatihan tentang penerapan pendidikan humanis di sekolah serta menambah guru PAI agar dapat secara intens menangani peserta didik yang mengalami permasalahan dalam pembelajaran dan permasalahan baik di lingkungan keluarga, masyarakat, dan sekolah.

\section{Daftar Pustaka}

Arikunto, S. (1998). Prosedur Penelitian. PT Rineka Cipta.

Daradjat, Z. (2015). Pendidikan Agama dan Pembinaan Mental. Bulan Bintang.

Fatmawati, N., Setyowati, D. L., \& Utomo, C. B. (2018). "Outdoor Study Activity by Utilizing Wonosoco Tourism Village as A Learning Resource of Social Studies". Journal of Educational Social Studies, 7 (1): 88-98.

Mahmud. (2011). Pemikiran Pendidikan Islam. CV. Pustaka Setia.

Majid, A., \& Andayani, D. (2004). Pendidikan Agama Islam Berbasis Kompetensi. Remaja Rosdakarya.

Moleong, L. J. (2009). Metodologi Penelitian Kualitatif. PT. Remaja Rosdakarya.

Rahman, M. (2013). Guru Humanis dalam Pendidikan Islam. STP, XXVIII(3).

Rochimah, N. A., \& Zaman, B. (2018). Pendidikan Moral AnakJalanan. Trussmedia Grafika.

Safitri, E. N., \& Zafi, A. A. (2020). Konsep Humanisme Ditinjau dari Perspektif Pendidikan Islam. AL-MURABBI: Jurnal Studi Kependidikan Dan Keislaman, 7(1), 78-89. http://ejournal.kopertais4.or.id/mataraman/index.php/murabbi/article/view/3842

Solichin, M. M. (2018). Teori Belajar Humanistik Dan dplikasinya dalam Pendidikan Agama Islam. Jurnal Islamuna, 5(1). 
Sugiyono. (2011). Metode Penelitian Kuantitatif, Kualitatif dan $R \& D$. Alfabeta.

Suyono, \& Haryanto. (2011). Belajar dan Pembelajaran (Pertama). Remaja Rosdakarya.

Zafi, A. A. (2020). Penerapan Nilai-nilai Moderasi al-Qur'an dalam Pendidikan Islam. Jurnal Studi Ilmu-Ilmu Al-Qur'an Dan Hadis, 21(1). https://doi.org/10.14421/QH.2020.\%X

Zaman, B. (2019). Urgensi pendidikan karakter yang sesuai dengan falsafah bangsa indonesia. AL GHAZALI, Jurnal Kajian Pendidikan Islam Dan Studi Islam, 2(1), $16-31$.

Zaman, B. (2020). Metodologi Pembelajaran Pendidikan Agama Islam (Teori dan Aplikasinya). Oase Pustaka.

Zuhairini. (2004). Metodologi Pembelajaran Pendidikan Agama Islam. UIN Press. 